\title{
Rasgulla—the ethnic Indian sweetmeat delicacy and its evolutionary journey through contemporary research
}

\author{
Tanmay Sarkar ${ }^{1,2^{*}+}$, Molla Salauddin ${ }^{1,3+}$ and Runu Chakraborty ${ }^{1 *}$
}

\begin{abstract}
West Bengal and Odisha, two distinguished provinces of India, are consecrated with prosperous animal resources. Both territories have substantially affluent traditional dairy-based products. Rasgulla is one of such kind of traditional Indian dessert made from milk casein with attractive white colour having a spongy, porous structure and spherical shape, popular all over the world for its taste, flavour and unique texture. It is mainly originated in the West Bengal and Odisha, through a cascade of ethnic gastronomic phenomena. Both the traditional and cutting-edge practice of rasgulla preparation has its own impact on the sensory attributes of the product. Researchers' approach to improve textural, colour and sensory qualities of this astonishing dairy product has an appulse on overall acceptability of the product. Different types of milk and coagulant have a tremendous effect on the final quality of the product in terms of nutritional, textural and palatability characteristics of rasgulla. To make this traditional sweetmeat more nutritious, fortification and enrichment of functional features have been studied. Anti-diabetic rasgulla has been prepared to conquer the diabetes mellitus through re-modulation in the extent of sugar used to process this sweetmeat. Shelf-life of casein based products is one of the main concerns for researchers, due to abundance of ample amount of nutrients for optimum growth of microorganisms, along with the warm and humid condition of Indian subcontinent which accelerates the microbial propagation. Though the product has immense nutritional and sensory idiosyncrasy as well as folk medicinal importance, it is yet to be explored in coetaneous medical sciences.
\end{abstract}

Keywords: Ethno-technology, Reginoal cuisine, Socio-religious food, Channa , Dandi Ramayana

\section{Introduction}

Most often ethnic foods are regional delicacies, evolved through geographical, historical and anthropological criteria of mankind. Intercultural relation and social reforms may act as the catalyst for ethnic food inheritance [1]. From the Vedic era to the pre-independence era, food acculturation is there for multiracial Indian culture [2]. Generally, ethnic foods are confined in the regional periphery may be due to cultural diversity, differences in

\footnotetext{
* Correspondence: tanmays468@gmail.com; crunu@hotmail.com

†Tanmay Sarkar and Molla Salauddin contributed equally to this work.

'Department of Food Technology and Biochemical Engineering, Faculty of Engineering and Technology, Jadavpur University, Jadavpur, Kolkata 700032, India

Full list of author information is available at the end of the article
}

perception of palatability, unavailability of raw materials, dependency on environmental factors, fauna and flora, shelf-life stability and obviously due to scarcity of skilled human resources. The intervention of modern technology may subdue these factors. Contemporary scientific research on ethnic foods may collapse the provincial boundaries and parallel socio-economic cultural communities may intercept each other by virtue of palatability, ethnicity and doctrinal comestibles. In India, since ancient time period, irrespective of vast cultural context milk is considered as an inevitable part of Indian food ecosystem and that is why the cow has been considered as a holiest and significant domestic animal in Indian civilization. Since $800 \mathrm{BC}$, cow was reported to be an

(c) The Author(s). 2021 Open Access This article is licensed under a Creative Commons Attribution 4.0 International License, which permits use, sharing, adaptation, distribution and reproduction in any medium or format, as long as you give

appropriate credit to the original author(s) and the source, provide a link to the Creative Commons licence, and indicate if changes were made. The images or other third party material in this article are included in the article's Creative Commons licence, unless indicated otherwise in a credit line to the material. If material is not included in the article's Creative Commons licence and your intended use is not permitted by statutory regulation or exceeds the permitted use, you will need to obtain permission directly from the copyright holder. To view a copy of this licence, visit http://creativecommons.org/licenses/by/4.0/. 
inherent part of Vedic culture and they referred cow as vara or blessing in their literature. Since ancient time irrespective of a different region in every Indian household, cow had become very common domestic animal due to its different beneficial characteristics [3]. Different milk and milk-derived products have always been the attention seeker due to their excellent nutritional profile and taste. As civilization evolved towards the level of upgradation, variation in different dairy-derived products also took place. Dairy derived products are mainly consisting of different types of sweets, cheese, ghee, yogurt, dahi, butter and paneer. In the Vedic literature Ghee from cow milk was referred to as manda and there was a mention of a special dish called saga which was prepared from buttermilk [3]. In Buddhism and Jainism culture also the use of milk was reported. Jains have dipped a cloth into milk and dried the cloth and later they prepared a reconstitute product called Kholas by using water and that dried cloth [3]. It is considered from different literature that there are six types of foodstuff according to their way of consumption. According to Bhojanakutūhala and Pākaśāstra or Pākakalā, Rasala is one of this foodstuff which indicates the food is to be taken by licking [4]. In Bhojanakutūhala, there is a detail description of indigestion causing agents, which include curd drink. It comes under Rasala group of food-stuff. This literature also provides information about how this type of indigestion can be cured. In Vãlmìki-Rāmāyaṇa Ayodhyäkhanda, there is a mention of rasala [5]; other literature like Pākaśästra reveals the mentioning of curd. In the Vedic era, the curd was quite popular. According to Rgveda, Somājuice and barley meal are mixed with curd and consumed thereafter. From Mahäbhärata and Vàlmìki-Ràmāyana, it is found that rasala is consumed as a sweetmeat prepared from curd [6]. A curd drink which is named as Sikharin̄i is also a type of rasala. Its preparation includes sugar, curd and spices. Types of Śikhariṇi are described by Amarakośa. From Pākaśästra and Arthaśästra [7], there is a mention of Kürcikā, which is actually 'inspissated milk', from the Arthaśästra the function of buttermilk is explained as it was served to dogs and pigs, whereas solid part of Kürcikā was served to soldiers along with foods and rest liquid part (kilāta) was given to cows with fodder. Kilāta is coagulated milk or curd or 'inspissated milk' which is applied to cheese. There is a broad range of dairy-derived sweets which are very popular for their mouth-melting taste and nutritional qualities. Rasgulla or sweetened cheese ball is a kind of dairy-derived sweet which is originated mainly in the eastern part of India. In the eastern region of India, Kolkata (West Bengal) and Puri (Odisha) are very popular old city and both are situated beside the Bay of Bengal. Colonist from European countries like Britain and Portugal came to this region of India, who have taught the people of Kolkata (West Bengal) how to make channa or chhana with fine texture and later which helped them extensively to develop rasgulla. Rasgulla is a very popular dairy-based sweet across all over India and it is also known as rasogolla or rosogolla or rasogulla or rosogulla or rasogola. It is basically a sweetened syrupy cheese ball which is white in colour (mainly) has a very soft texture and excellent taste.

In the context of Indian rich cultural heritage along with other sweet products for a long time, rasgulla has maintained its signature presence with unique ethnicity. Being originated from the eastern region of India specifically from West Bengal and Odisha today rasgulla and rasagola has established its identity across the globe.

\section{History of rasgulla}

The documented historical comprehensive cognition about the rasgulla is not enough. According to the folk tale, it is believed that it has been invented in Bangladesh (around the seventeenth century) and later popularise by Nabin Chandra Das (1868 A.D.) in West Bengal. Though as per the Dandee Ramayana, rasgulla existed in Odisha from 1500 A.D. [1, 3], though the science of soft and smooth channa processing is unveiled to Indians by the Portuguese colonist. Channa prepared by skilful artisan followed by soaking into sugar syrup with adequate consistency and the proper combination of heating ultimately produce the sweet syrupy cheese ball or rasgulla.

\section{Historical and geographical perspective behind the origin of rasgulla}

Two different ethnic bases are there about the invention of rasgulla in West Bengal $\left(22.5726^{\circ} \mathrm{N}, 88.3639^{\circ} \mathrm{E}\right)$ and Odisha $\left(19.8135^{\circ} \mathrm{N}, 85.8312^{\circ} \mathrm{E}\right)$. Both the provinces of India possess a heritage food culture. These adjacent states are located in the river irrigated eastern part of India and thus have plenty of green fields that ultimately help the animal husbandry. The abundance of milk and fondness of sweetmeat particularly in the eastern portion of India lead to the invention of several dairy delicacies (Fig. 1).

\section{Historical background in West Bengal}

The basic raw material of rasgulla is channa which is coagulated casein. Channa has been well documented in Chitanya Charitamrita during the time of Chaitanya Mahaprabhu [8]. Sweets made of Channa is connected to 500 years in Bengali's life. Three sweets of Channa, i.e. Channa Chatka, Channa Pitha, Channa Manduah, are documented in Sri Sri Gouriyo Baisnab Abhidhan [9]. Channa chatka, channa pitha and channa manduah have been not 'Rasgulla'. The present form of rasgulla has been invented later on after different experiments. 


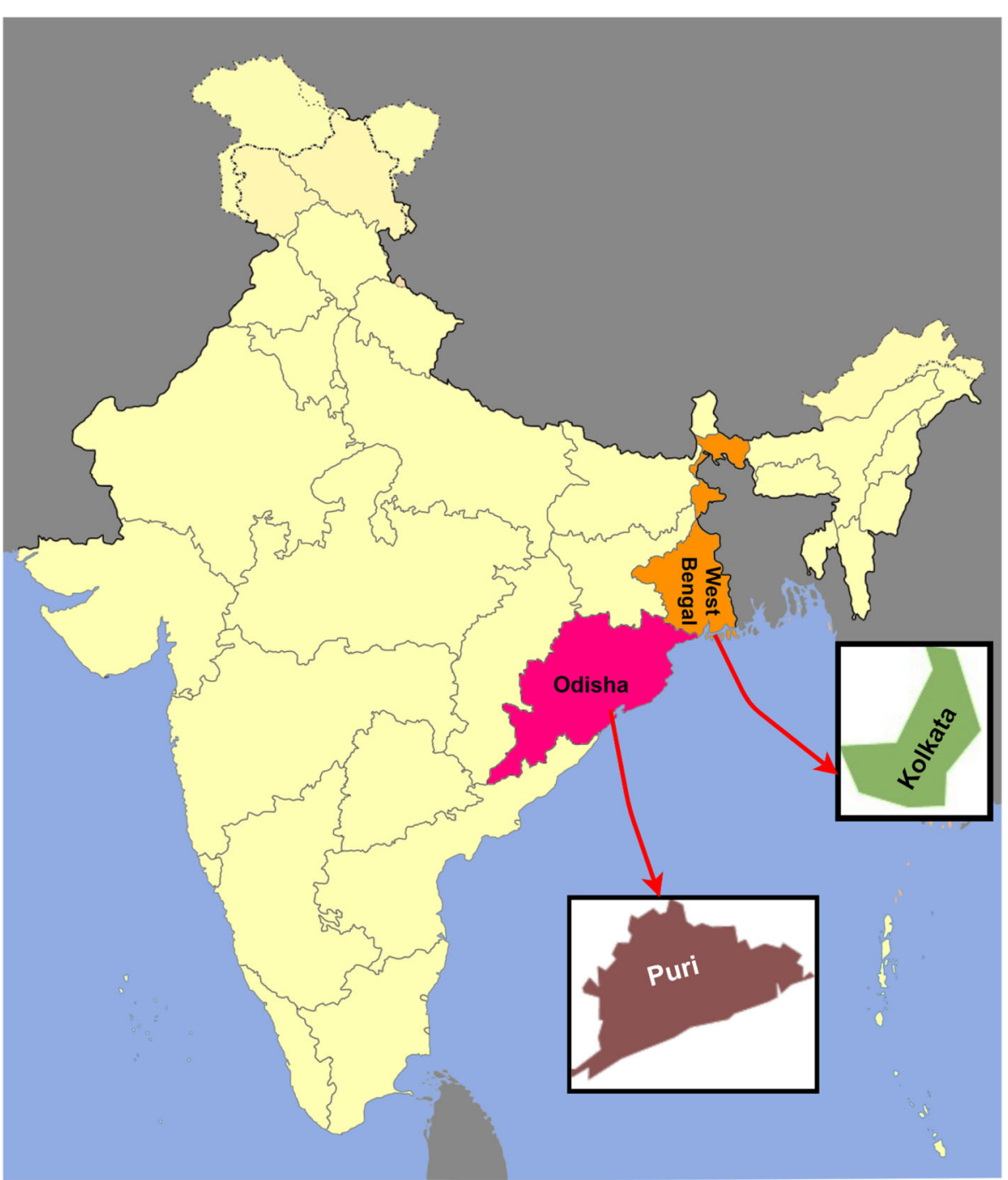

Fig. 1 Map of India. West Bengal and Odisha, two states in close proximity with Indian Ocean. Kolkata, the state capital of West Bengal, and Puri an ancient city of Odisha are the places of origin of the rasgulla

\section{Historical background behind the origin of rasgulla in West Bengal}

The technology to process and synthesize high-quality chhana used to make sweets was taught specifically in Bengal by the Dutch and Portuguese colonists during the late eighteenth century. Chhana processing was introduced as a by-product at a very small scale as the production of Dutch cheese was done only in Bengal. The earliest evidence of any foreign influence on Indian food-products could not predate $1610 \mathrm{CE}$ and chhana, itself, or its derived products were not commercialized or consumed in India before this foreign influence. Chhana-based products were deemed unfit for consumption because it is obtained through the curdling of milk into torn and broken clumps which were signified as a spoilt milk product [10].
From the writings of Panchanan Bandyopadhyay, it is found that at Fulia located in Nadia district of Bengal a confectioner named Haradhan accidentally prepared rosogolla [11]. In Chandimangal, written in the early sixteenth century, it is well documented the term chhana and the product made out of it chhana naru [12].

The distinctive rasgulla is characterized by spongy white small balls of Indian cottage cheese (chhana) with $2.5-4 \mathrm{~cm}$ of diameters and cooked in sugar syrup till attainment of soft consistency along with high binding capacity. Before the fifteenth century in ancient India, the word chhana was not documented. It is non-existent in any classical dictionary of Sanskrit text. In some ancient texts, chhana has been identified as amiksha, dadhikurchka and kilat. Chhana originated from the word china (Sanskrit word) which stands for a broken, torn 
and fragmented dairy product. Chhana has been considered as a sacred bhog (offering) to Hindu deity Gopal (childhood avatar of Lord Krishna) [13].

Sri Chaitanya Mahaprabhu (1486-1534) had an affinity for chhana as a portion of the daily diet. Chhana prepared in that era was coarse, granular in texture and scrambled largely with inferior binding capacity. Lactic acid-rich whey was used generally to produce smooth and finetextured chhana having higher binding capacity which was not known for about 700 years ago. Acetic acid coagulated chhana processing was introduced in Bengal around 1790-1820. Chhana produced in India before 1790 was coagulated by ascorbic or citric acid obtained from natural fruit; this was not an appropriate one for sweetmeat production. This kind of chhana was used to produce chhana-bora (fried product) and chhana chatka (pressed chhana with caramel) [14].

Rasgulla's invention was deeply rooted in science and experimentation with a recorded history of development by Nobin Chandra Das. Regardless of integrating the prevalent assortment of chhana utilizing Dutch and Portuguese innovation, sweet confectioners all across Bengal and beyond were unable to tie it into a sweet delicacy since clusters of chhana in bubbling sugar syrup would either transform into an unbending caramel consumed crump or self-destruct into parts as opposed to embellishment into a homogeneous round structure. One prominent example of such unsuccessful attempts to procure a sweet delicacy that resulted in a brown burnt clump of chhana was often called Dela-Rossogolla in some historical texts [15].

It took 3 years of experimentation for Nobin Chandra Das (between 1865 and 1868) to finally develop this unique delicacy called Rasgulla, purely made out of chhana, and bearing the texture and attributes of a sponge. His magnum opus not only became synonymous with the Bengali identity but reached the status of the 'National Sweet Dish' of India, today. He has been hailed as the 'Columbus of Rossogolla' for almost 150 years and it is indeed humiliating to the identity and culture of Bengal if the claim for his creation is misappropriated today. $\mathrm{He}$ makes little chunks of casein (curds) and boiled them in hot sugar syrup. The outcome is a delicious, supple sweet with a one of a kind, particular taste. Nobin Das dedicates it to the Rasgulla, and a legend has conceived [16].

\section{Historical background behind the origin of rasgulla in Odisha}

In Odisha, it is well known as rasagola. Since long before the Odisha Rasagola has a rich heritage as it is connected with world eminent Puri Jagannath (Hindu god) Temple. According to the temple's rituals of Niladri Bije, on behalf of Shree Jagannath the Rasagolabhoga is traditionally offered to Devi Lakshmi (Hindu goddess) which is the duty of Bhitarachha sebaka [17].
Jagamohana ramayana or Dandi Ramayana which has been sung and composed at Puri Jagamohana temple has the mention of rasgullas (Fig. 2) [18]. Extensive representation of chhena, rasgulla, and other chhena-based sweetmeat products have been found in the 'Ajodhya Kanda' part of Jagamohana Ramayana [18]. It is described that on the way to get back Lord Rama, his two brothers Bharata and Satrughna came in contact with sage Bharadwaj, and at that time sage Bharadwaj presented various types of food items to them including different chhena-based product namely chhenapuri, chhenaladu, rasagola and rasabali. In the book, Utkal Bhramanam has several utterances of rasgulla [19]. Fakir Mohan Senapati acknowledged the use of rasagola in Odisha during those days. Poet Damodar Pattanayak described the acclaimed historic fair of Cuttack (Odisha) namely Bali Jaha (Journey to Bali island of Indonesia) and wrote about the glorious presence of rasgulla in the sweetmeat outlets [19].

\section{Process of rasgulla preparation}

Two typical processes are practiced in West Bengal and Odisha to prepare Rasgulla and Odisha rasagola respectively.

\section{Traditional preparation method followed in West Bengal}

In Fig. 3, the traditional process of rasgulla preparation is described in a flow chart. The main ingredients are cow milk, sugar, water and whey. Initially, the sugar syrup is prepared by dissolving sugar in water. Then the raw milk is boiled and chhana is prepared from it by means of a coagulating agent like lemon, plant-based enzymes or rennet. The raw hot chhana is then taken into a muslin cloth. The excess whey is drained out. Then the hot channa is placed under normal running water to make it cool. Then the chhana is pressed hard to as much as the possible extent to remove out the excess water. Then the pressed chhana is placed in a roundshaped wooden plate known as barkosh. Then by using the palm of both hands continuous kneading and pressing operation have been done till the desired smooth texture is achieved. After that small chhana pieces are cut-out and round shape is made by using hand palm. Then these small balls are dropped into the boiled sugar syrup. During boiling, cold water is added to sugar syrup in a certain interval of time to settle down the chhana balls; otherwise, the chhana balls are gathered together and settled upwards. The boiling process is continued for $15 \mathrm{~min}$, and after that, the small rasgullas will slowly start to enlarge in size, and rasgullas are removed out from boiled sugar syrup after desired size and shape are achieved. Immediately after the rasgullas are removed out from boiled sugar syrup, all the rasgullas are put into sugar syrup containing 35-40\% sugar. After cooled down to room temperature, rasgullas are ready for consumption [20] (Fig. 4). 


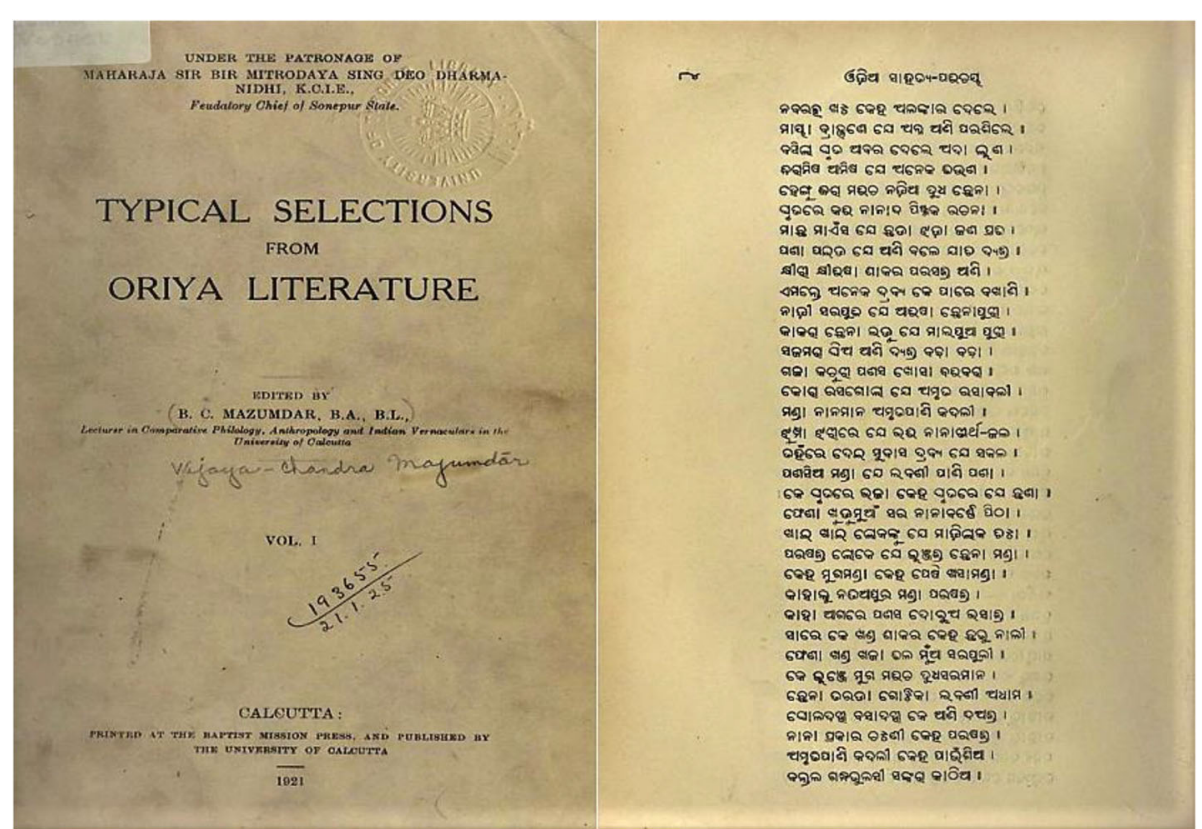

Fig. 2 Traditional customs related to rasgulla on Niladri Bije (i.e. the concluding day of Chariot Festival or Ratha Yatra) of Lord Jagannath. Title page of the book ('Typical selections from Oriya literature') published in 1921 by the University of Calcutta, edited by Bijoychandra Mazumdar, who collected and edited the Balaram Das's fifteenth century work Dandi Ramayana (Oriya version of the Sanskrit epic of ancient India). In this book the mention of rasgulla is found in the page number 119. The Dandi Ramayana stated that several dessert items like gaja, rasabali and chena puri were offered (bhog) to Lord Jagannat and rasgulla was one of them which was offered to him from that historical period

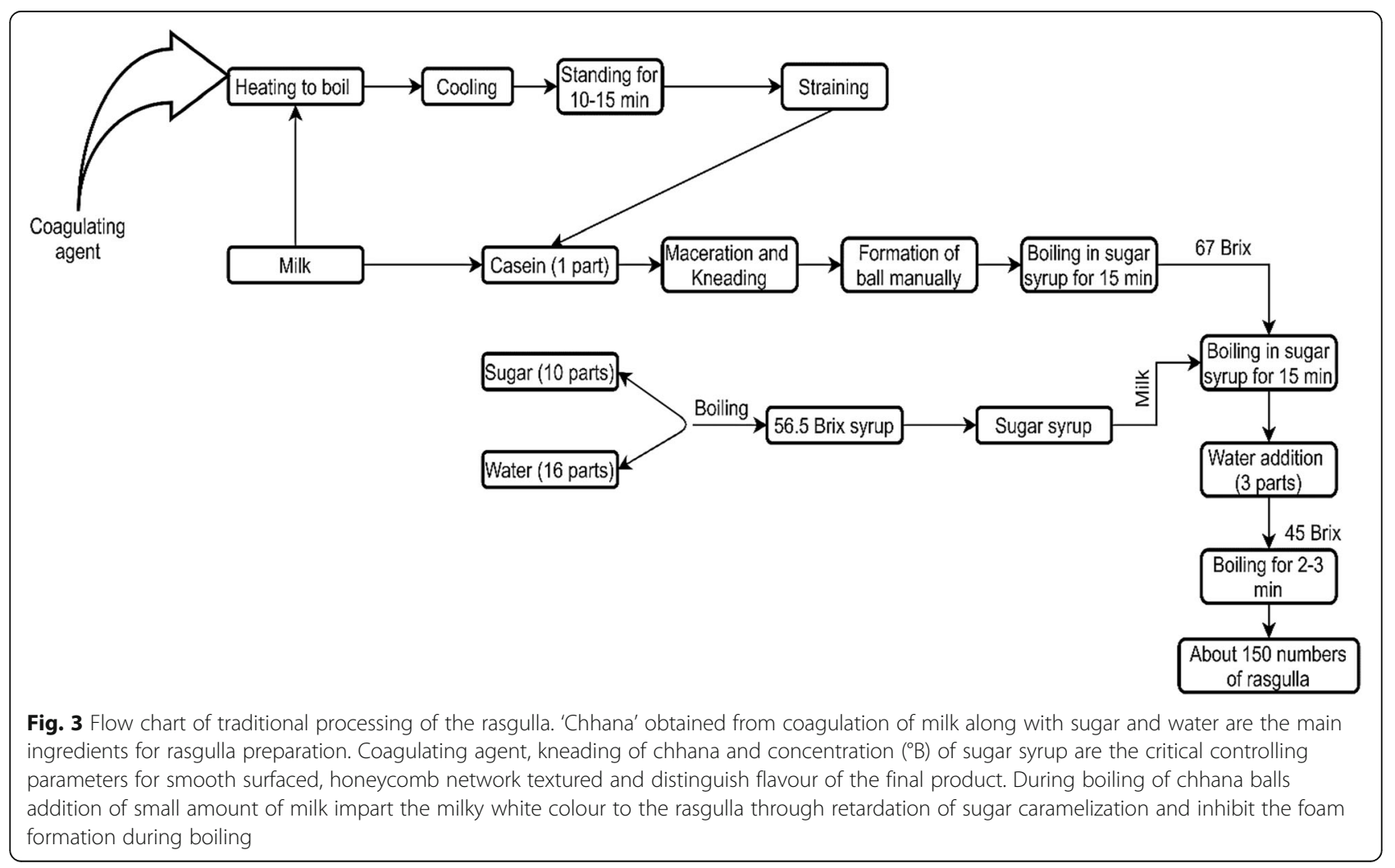



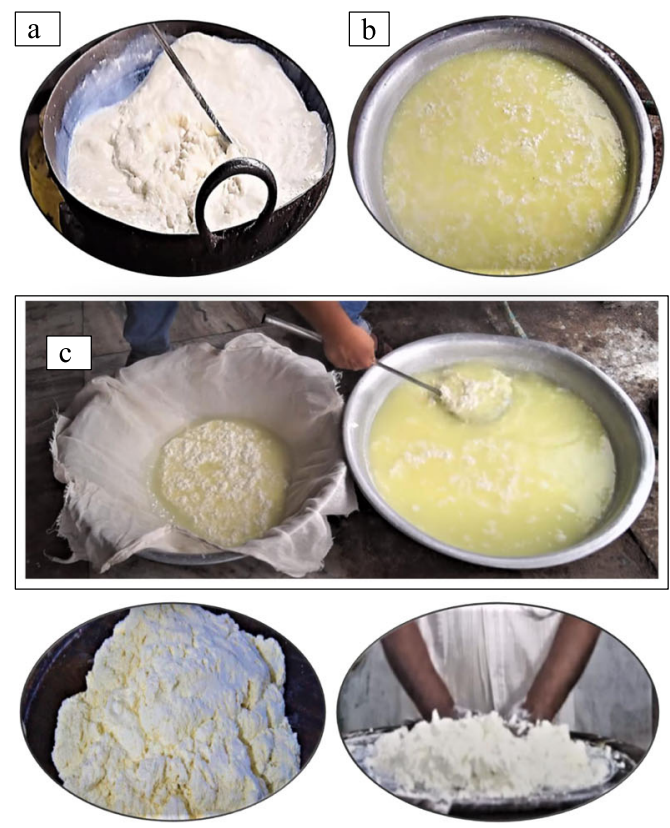

d
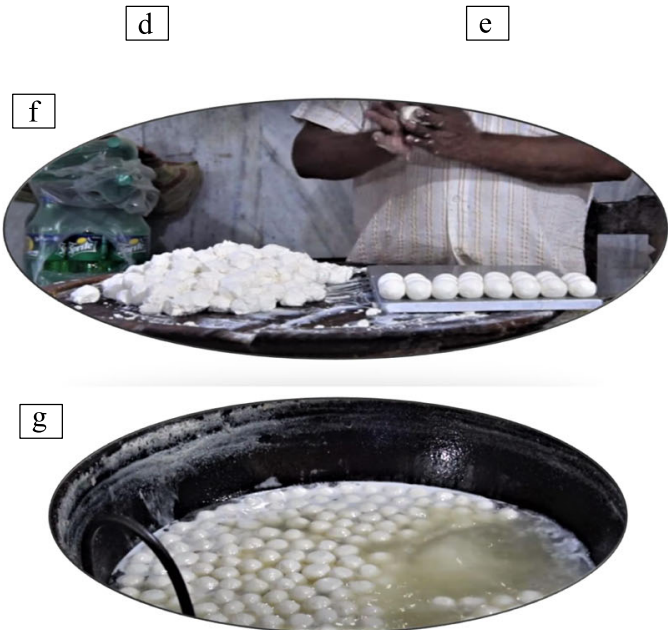

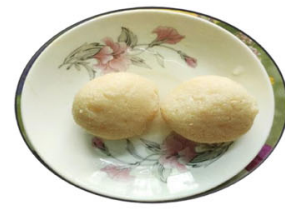

$\mathrm{h}$

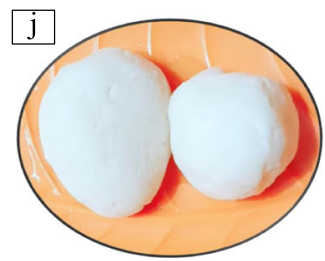

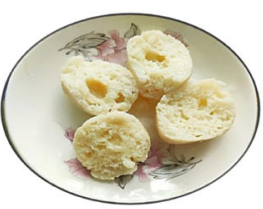

i

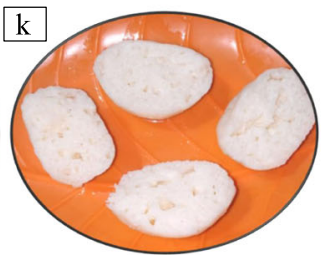

Fig. 4 The array of ingredients and their sequential forms for rasgulla processing. a Boiled milk (15 min of boiling). b Coagulated milk (citric acid or calcium lactate as coagulating agent). c Strain: chhana poured in white muslin cloth (muslin is an ethnic textile product being produced in Bengal from ancient time) which is used generally and twisted to expel out the whey. Some weight is applied on it also for better removal of water. $\mathbf{d}$ Chhana. $\mathbf{e}$ Kneading: generally barkosh or chhenapata (wooden plate) is used, as both of the provinces have their heritage in wooden work. $\mathbf{f}$ Ball formation by hand. $\mathbf{g}$ Boiling in sugar syrup. $\mathbf{h}$ Traditional rasgulla. i Texture of traditional rasgulla. $\mathbf{j}$ Sponge rasgulla. $\mathbf{k}$ Texture of sponge rasgulla of Kolkata respectively

\section{Traditional preparation method followed in Odisha}

To prepare Odisha Rasagola ingredients are sugar, milk, suji, white flour, elaichi (powdered small cardamom) and soft textured chhena. The preparation process starts with the mixing of white flour, suji, chhena and elaichi powder together followed by spreading the mixture on the chhenapata by hand and again gathered to frame an adjusted shape and squeezed with hand pressure. The same process is repeated several times within a period of 20 min. This whole kneading process is known as chhennachakata locally. Then small chhena balls are boiled in the prepared sugar syrup at a temperature of $110{ }^{\circ} \mathrm{C}$ for $25 \mathrm{~min}$. After rasagola formation, they are taken off from the Kadai and put into hot water $\left(100{ }^{\circ} \mathrm{C}\right)$ for some time and then another sugar syrup is added to it. Odisha rasagola is well known for its natural colour development where no artificial colour is used and the colour is totally formed by blending the fresh sugar syrup in 3:2 ratios. The sugar mixture is cooked for $50 \mathrm{~min}$ at a temperature of $110{ }^{\circ} \mathrm{C}$ where natural colour is developed by the caramelization process [21].

\section{Mechanization of ethnic processing method for rasgulla preparaion}

In West Bengal, some sweets shops are started making rasgulla by using fully mechanized way to meet the increasing consumer demand. About $67 \%$ of the increase in the rate of production is observed per year (20182019). One of such types of mechanized preparation of rasgulla (Fig. 5) is given below.

In kneading purpose, a screw-type conveyor is used where $10 \mathrm{~g}$ of lumps portion is made out the kneaded chhana [22]. In order to give spherical shape to chhana balls, lump portions are placed on a spinning disc. Another chhana kneader has been developed by Karunanithy et al. in which the kneader consists of kneading chamber, feed hopper, reduction gearbox, rotor, outlet and motor [23]. Kneading chamber is attached to three different rotor models. A 25-mm pitch screw is attached to both ends of the rotor shaft. The rotor shaft is attached to spokes in the 


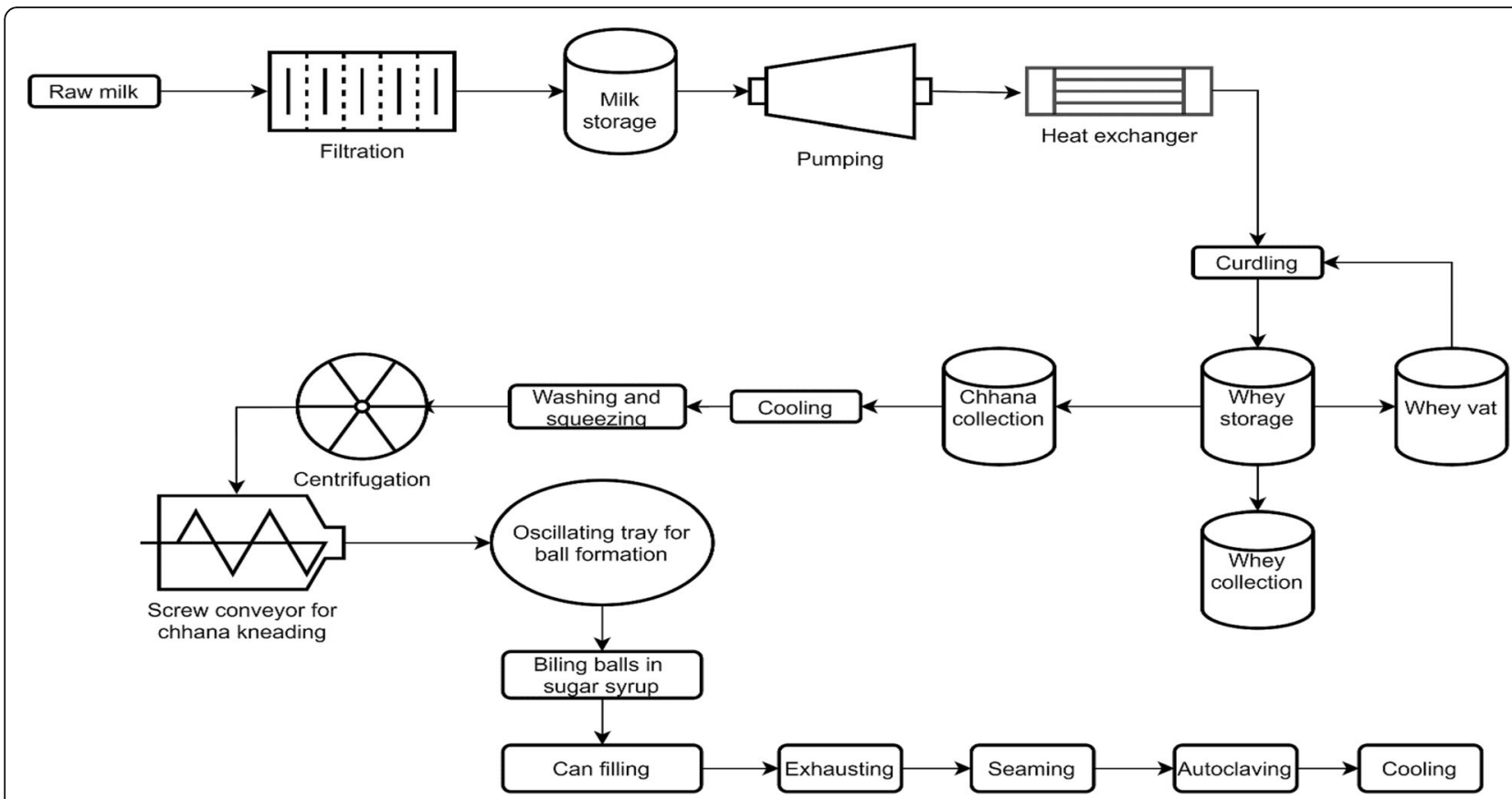

Fig. 5 Flow chart for mechanized preparation of the rasgulla. To increase the shelf-life and to diminish the manual handling machine aided processing along with canning is employed. Quality of raw milk, hygiene and cleanliness of chhana collection unit are the critical junction to taken care of. Kneading and ball formation are done with screw conveyor and oscillating tray respectively, the crucial sections responsible for reduction of processing time for rasgulla preparation. Actual overlap, minimum tightness and body hook butting during seaming and temperature, pressure during autoclaving are the principle factors determine the sensory quality and storage stability of canned rasgulla

helical pattern. Speed of the rotor shaft is maintained at $93.46 \mathrm{~cm} / \mathrm{s}$. Karunanithy et al. has used an oscillating tray to make balls. $2.5 \mathrm{~g}$ of chhana lumps are portioned manually [23]. To make spherical balls, 150 lumps are placed in ball former. After the oscillation operation, the lumps are formed to a spherical shape within $15 \mathrm{~min}$. Then cooking is continued in $50^{\circ}$ Brix sugar syrup for $15 \mathrm{~min}$. Boiling syrup temperature is maintained at 105 to $110{ }^{\circ} \mathrm{C}$. Increase in the slope of ball forming unit and stroke length decrease porosity of rosogolla. After that, they are kept at 40 ${ }^{\circ}$ Brix sugar solution with the duration of $16 \mathrm{~h}$ [24]. Quality parameters of mechanically kneaded chhana, samples collected from the market and control samples are quite comparable. Samples are collected from the sweet shop; chemical composition, colour, expressible juice and porosity and sensory score are the parameters taken under consideration. The obtained result shows that expressible juice, porosity, volume expansion and percentage of absorbed sugar syrup are higher for the chhana plied in the machine with balls shaped at $5-\mathrm{cm}$ stroke length and 200 strokes/min for SS (stainless steel) plain surface with $0 \%$ incline and practically identical with control while expressible juice, porosity is in the scope of the market sample [24] (Fig. 6). Mechanically kneaded chhana and chhana balls produce better quality in respect of colour, hardness and overall acceptability.

\section{Amended forms of traditional rasgulla}

Modification of traditional rasgulla has been reported by researchers (Table 1). Bandyopadhyay et al. used carrot paste on normal dairy rasgulla and studied different sensory and physical parameters [37]; Suryawanshi et al. used isabgol powder at different concentration in normal dairy rasgulla and studied acidity, $\mathrm{pH}$ and proximate composition in line with normal rasgulla [26]. Coconut sap syrup at different percentage along with the sugar syrup may be able to lower sucrose content and higher protein content compared to traditional dairy rasgulla $[27,30]$. Chavan et al. used milk having lower fat content in a different range to develop low-fat rasgulla and has studied different sensory characteristics along with proximate composition in line with normal dairy rasgulla [28]. Pramanick et al. has developed a special type of rasgulla by using tulshi leaf extract to enrich normal dairy rasgulla nutritionally [29].

\section{Fortification of rasgulla for better nutrition}

Chakraborty et al. have fortified normal dairy rasgulla by using potato powder and has developed a new type of rasgulla which is more delicious and nutritionally rich compared to normal dairy rasgulla [32]. Fortification in dairy rasgulla has been reported by Sarkar et al. and Bandyopadhyay et al. where normal dairy rasgulla is 

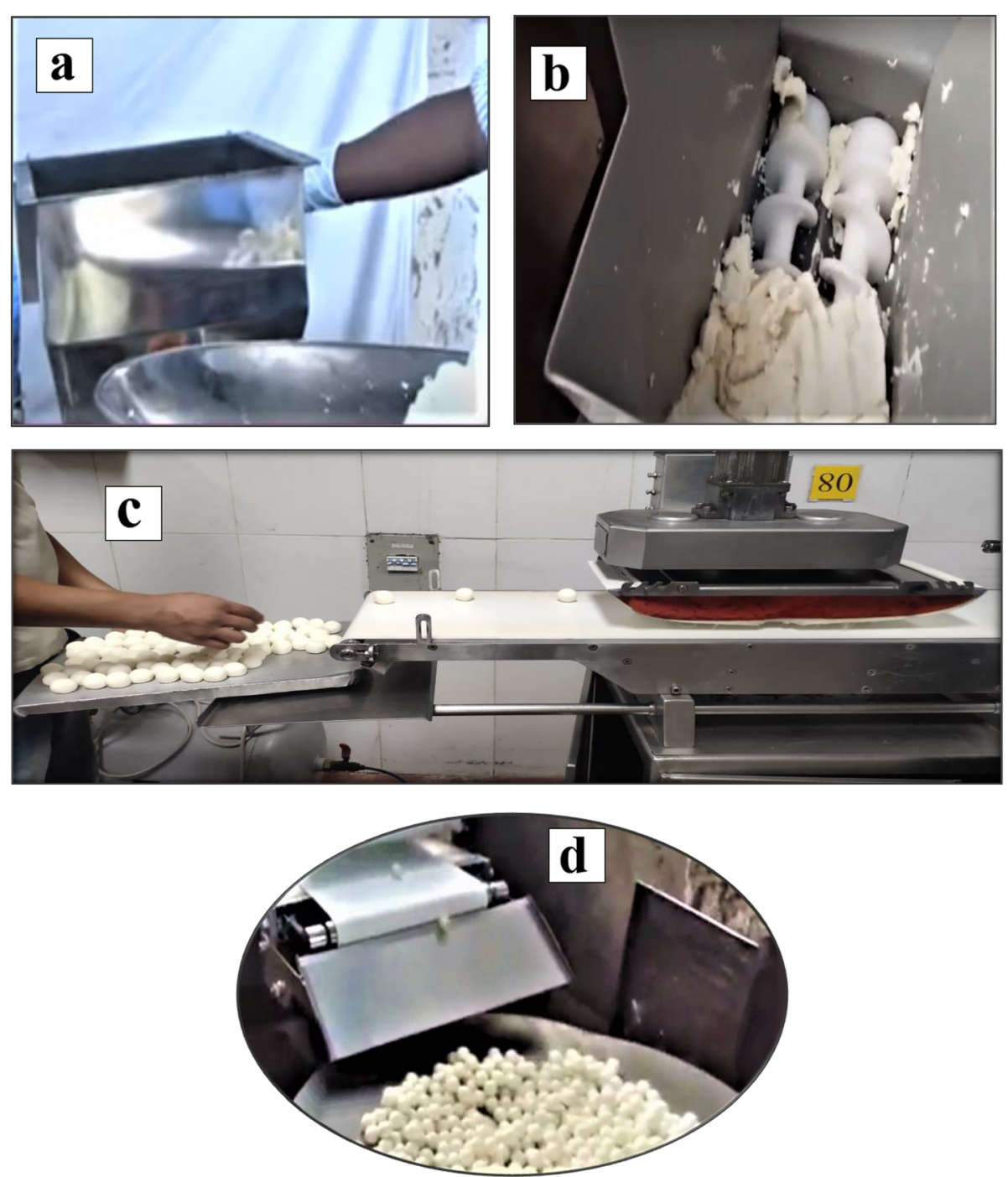

Fig. 6 The visual representation of segments of industrialized rasgulla processing. a Hopper: capacity is 3-30 kg of chhana per batch. b Screw conveyor: for kneading of chhana, generally twin screw. c Ball forming unit: balls with 10-30 mm of diameters and 2-20 g of weight can be produced with capacity $2000-8000$ balls/h, conveyor belt: speed $2-15 \mathrm{~m} / \mathrm{min}$. d Rotating plate: capacity of 3000 pieces/h. The machine is $190-$ $250 \mathrm{~cm}$ and $150-165 \mathrm{~cm}$ in length and height respectively; air pressure $5 \mathrm{~kg}$ and $0.9 \mathrm{ft}^{3} / \mathrm{min}$; made of SS 304

fortified by using pineapple and carrot paste [25, 31]. Rasgullas are fortified with homogenized carrot paste in range of $10-50 \%$ and finally colour, sensory parameter and compression test are done in line with normal dairy rasgulla. Rasgulla fortified with $10 \%, 20 \%$ and $30 \%$ carrot paste is found better than normal dairy rasgulla in terms of protein content, sensory profile, fat content, beta carotene retention and colour development.

\section{Diabetic rasgulla}

Being the diabetic capital of the world, in India, the number of diabetic patients is abruptly increasing. To combat against diabetics, different types of substitution of sugar are used for various types of application. In the case of rasgulla, sugar syrup plays a very important role in the whole preparation process and that is why various studies have been reported to have the different formulation of partial or complete sugar substitution. Incorporation of $40 \%$ sorbitol and aspartame mixture instead of sugar syrup in the preparation of rasgulla resulted in low calorie diet rasgulla [38]. Traditional dairy rasgulla prepared with stevia (a non-nutritive sweetener) along with sugar in a range of proportions resulted in formation of low calorie diabeties friendly rasgulla [27].

\section{Colour and texture modification of traditional rasgulla}

Basically, rasgulla is a white-coloured sweet dessert, but due to incorporation of different other materials in rasgulla for various purposes colour development also occurred in different types of rasgulla. The development of 
Table 1 Different types of rasgulla and their nutritional composition

\begin{tabular}{|c|c|c|c|c|c|c|c|}
\hline SL NO. & Type of rasgulla & Moisture (\%) & Fat (\%) & Protein (\%) & Ash (\%) & Carbohydrate (\%) & Reference \\
\hline 1. & Low fat rasgulla fortified with beta carotene & $54.48 \pm 1.92$ & $4.90 \pm 0.06$ & $4.84 \pm 0.07$ & $1.60 \pm 0.03$ & $38.80 \pm 0.56$ & [25] \\
\hline 2. & $\begin{array}{l}\text { Rasogolla by incorporating isabgol (Plantago Ovata) } \\
\text { powder }\end{array}$ & 54.84 & 4.50 & 4.80 & 0.90 & 34.96 & [26] \\
\hline 3. & Anti-diabetic rasgulla by incorporating stevia & $47.52-52.06$ & $7.1-7.5$ & - & - & $38.55-39.14$ & [27] \\
\hline 4. & Low-fat rosogolla & $49.10 \pm 1.25$ & $7.16 \pm 0.23$ & $8.69 \pm 0.45$ & $1.09 \pm 0.01$ & $45.42 \pm 1.71$ & [28] \\
\hline 5. & Rasgulla by incorporating tulshi & - & 5.40 & 12.30 & - & 48.21 & [29] \\
\hline 6. & $\begin{array}{l}\text { Low sugar dairy rasgulla by using coconut } \\
\text { sap syrup }\end{array}$ & $52.20 \pm 0.07$ & $5.62 \pm 0.17$ & $6.82 \pm 0.13$ & $1.06 \pm 0.06$ & $38.55 \pm 0.38$ & [30] \\
\hline 7. & Rasogolla fortified with potato powder & $48-52.3$ & $6.42-7.58$ & - & - & - & [31] \\
\hline 8. & Pineapple rasgulla & $47.85 \pm 1.88$ & $6.58 \pm 0.55$ & $7.22 \pm 0.69$ & $1.09 \pm 0.02$ & $29.62 \pm 1.01$ & [32] \\
\hline 9. & $\begin{array}{l}\text { Rasogolla from buffalo sweet cream buttermilk } \\
\text { fortified with cow milk }\end{array}$ & 53.4 & 2.47 & 7.6 & 2.1 & 2.2 & [33] \\
\hline 10. & Rasogolla & 54.86 & 4.9 & 5.05 & - & 34.35 & [34] \\
\hline 11. & Rasogolla & 37 & 4.2 & 6.8 & - & 51.9 & [35] \\
\hline 12. & Rasogolla made from fresh cow milk & 41.8 & 7.9 & 5.58 & - & 43.83 & [36] \\
\hline
\end{tabular}

The table describes the compendium of the scientific exploration of nutritional facts of traditional rasgulla and its different moiety. From the table, it is evidenced that researchers ameliorate the protein, fat and carbohydrate compositions of the traditional rasgulla, for better organoleptic and digestion characteristics. All the values are represented in percentage basis. The nutritional composition of the last entry of the table, i.e. serial number 12 (rasgulla made from fresh cow milk) stands for the traditionally processed rasgulla

characteristics yellowish-red colour is observed in carrot paste fortified rasgulla [37]. Significant changes in colour development is there due to incorporating isabgol in normal dairy rasgulla [26]. Sometimes due to overcooking and prolonged boiling in sugar syrup cause a brown colour development in dairy rasgulla due to the Maillard reaction. So cooking time and boiling temperature are considered as a very crucial parameter for the final rasgulla quality.

Rasgulla is popular basically for two things - taste and mouth melting spongy juicy texture. In preparation of rasgulla, the most challenging and crucial thing is the texture development maintaining all standard properly. Quality of milk as well as the quality of channa has a high impact on the final texture development of rasgulla. The variation in fat content in milk causes significant changes on the moisture content of channa which results in textural changes of rasgulla and best rasgulla with a very spongy texture and the porous structure is obtained from the channa prepared from $5 \%$ fat content milk [33]. Changes in the textural profile are observed for rasgulla prepared with sorbitol and aspartame instead of sugar syrup and increase in fat content resulted in an increase in hardness and decrease in cohesiveness [38]. After 20 min cooking in $55^{\circ}$ Brix sugar syrup the values of hardness, cohesiveness and springiness attained at a fixed value and it is observed that the cohesiveness increased during cooking, probably due to settling of the casein network in rasgulla [39]. The pore size of rasgulla prepared from cow milk range between 0.8 and $1.25 \mathrm{~mm}$ [28]. A significant decrease in hardness and increase in springiness value of rasgulla sample are observed for fortified with potato powder [32]. A similar kind of results for rasgulla sample fortified with carrot and pineapple paste is observed [25, 31].

\section{Effect of sugar syrup on rasgulla properties}

Two types of sugar syrup are used-cooking syrup and soaking syrup. The cooking syrup is used to boil the small channa balls and after boiling the rasgulla are dipped in soaking sugar syrup for soaking purpose. Concentration and strength of cooking sugar syrup affected the shelf-life of rasgulla and obviously the desired sweetness and shelf life [40]. The cooking sugar syrup strength should be varied from $50-60{ }^{\circ}$ Brix for optimum sweetness, prolonged shelf life and spongy texture [34, $35,40]$. The effect of sugar concentration on the final shape of rasgulla was found negligible.

After completion of cooking, rasgullas were dipped in a sugar syrup having concentration less than that of cooking syrup. The dipping of rasgulla in sugar syrup having $40^{\circ}$ Brix concentration for overnight time period resulted in optimum texture formation $[35,41]$. The texture stabilization of chhana balls of 1-2-cm diameter required to be dipped for $4 \mathrm{~h}$ in $40-45^{\circ}$ Brix sugar syrup [42]. The proper development of rasgulla texture chhana balls of $6 \mathrm{~g}$ weight had to be soaked for $16 \mathrm{~h}$ in $40 \%$ sugar syrup at room temperature [43].

\section{Effect of types of milk on rasgulla properties}

Types of milk also have a vital impact on the quality of rasgulla as the nutritional composition of milk differ for 
different types of milk. Generally, for rasgulla making, cow, goat and buffalo milk are used. The cow milk chhana was more preferable for rasgulla due to its tender body, smooth texture and light yellow colour, whereas buffalo milk chhana had hard, granular and coarse texture $[44,45]$. Crossbred cow's milk containing $4 \%$ fat content was found as optimum quality chhana for preparation of rasgulla [44]. Rasgulla were made from pure cow milk, pure buffalo milk and 50:50 mixture of cow and buffalo milk and it was found that rasgulla made from pure cow milk was best in terms of organoleptic properties than other two types of rasgulla [46]. Rasgulla prepared from milk contained less than $4 \%$ fat caused the formation of hard body and texture of rasgulla while the milk with more than $4 \%$ fat caused the formation of rasgulla with slippery texture [45]. Researchers experimented with different fat-containing milk to make rasgulla varying from 3 to $4 \%$ fat, in some cases different types of goat milk having $1-6 \%$ of fat [47, 48]. Channa prepared from a mixture of buffalo milk and water in a ratio of $3: 1$ along with $0.05 \%$ sodium citrate as coagulant resulted in improvement of channa quality for rasgulla preparation [49]. Milk with $4 \%$ fat was found to be the best for the making of rasgulla with excellent organoleptic properties.

\section{Effect of coagulant on channa quality}

The chemical quality of rasgulla as affected by utilizing chhana obtained using coagulants of varying strength. It was seen that except for moisture and carbohydrate content all other nutritrional constituents of rasgulla were insignificantly $(p>0.05)$ influenced by the coagulant types or their strength. Channa with moisture content in the range of $55-58 \%$ was found to be best for the optimum quality of rasgulla [40]. The highest fat content was noted for rasgulla prepared from chhana made using $0.5 \% \mathrm{CA}$ coagulants. $1.63 \%$ ash content was observed for rasgulla made from chhana prepared using $0.5 \%$ CA coagulant [50]. The lactic acid coagulated channa resulted in better quality rasgulla than citric acid coagulated channa. As a coagulant citric acid resulted in the retention of lower moisture content in channa than lactic acid which increased the cohesiveness of channa and thus responsible for more elasticity of channa. Channa coagulated by using citric acid had higher cohesiveness than lactic acid channa and according to them this might happen due to higher acidity of citric acid than lactic acid [51]. Channa coagulated by calcium lactate resulted in harder texture because of incorporation of higher calcium content in channa [52]. It was found that calcium coagulated channa had lower cohesiveness than citric acid coagulated channa and this may be due to holding capacity of calcium ions which resulted in more moisture retention than that of citric acid coagulated channa [52].

\section{Effect of coagulants on the sensory attributes of rasgulla}

Use of different coagulants in channa making had a crucial impact on the final sensory quality of rasgulla and that was considered as the most important factor in order to adjudge the rasgulla quality [53]. Chhana coagulated using calcium lactate resulted in lower body and surface score because of too much moisture retention bringing about the frail, however smooth surface [54]. Chhana that were coagulated using lactic acid resulted in grainy texture, while citric acid resulted in pale chhana. It was suggested that lactic acid over calcium lactate can be utilized as a coagulant in channa making for rasgulla. A comparable outcome for cow milk chhana was observed [55]. Cow milk chhana that was produced with calcium lactate provided a delicate body along with smooth surface and wonderful flavour [56].

\section{Nutritional composition of rasgulla}

There are significant differences $(p<0.05)$ in the moisture content of rasgulla collected from different sources as shown in Table 1. Rasgulla's moisture content generally varies from 37 to $54.86 \%$. The higher moisture content is related to good quality, flavour and texture of rasgulla [54]. The average moisture content is maximum for rasgulla made from cow milk, followed by made from buffalo milk and goat milk [33]. An appealing flavour in rasgulla can be achieved with chhana containing 62.5$63.5 \%$ moisture [57]. Therefore, it can be concluded that there is significant correlation between overall textural quality and moisture content of rasgulla $[58,59]$.

From Table 1, it has been seen that the fat content of rasgulla varies from 2.47 to $7.58 \%$. Bhattacharya et al. report that use of milk having high-fat content resulted in rosogolla having a higher amount of fat percentage [40]; increased fat content in product tends to soften the body and improves the texture of the resultant product. Milk with $5.41 \%$ fat content results in rasgulla with superior quality [60]. It was observed that the rasgulla prepared using buffalo milk has a significantly higher amount of fat than the other samples [33].

From Table 1, it has been seen that the protein content of rasgulla varies from 3.91 to $7.6 \%$. The quality of rasgulla increases with an increase in protein amount. $6.62 \%$ protein content in milk produces spongy rasgulla; the same is observed by Desai et.al. for $6.7 \%$ protein content in milk $[60,61]$. Traditional rasgulla prepared from buffalo milk possess higher protein content, followed by rasgulla prepared from goat and cow milk [60].

From Table 1, it has been seen that the ash content of rasgulla varies from 0.84 to $2.1 \%$. The highest percentage of ash for the rasgulla prepared from buffalo milk, 
followed by rasgulla prepared from goat milk and cow milk, which may be due to higher amount of total solids content in buffalo milk compared to cow and goat milk [60]. The sponginess of the product decreased due to the higher ash and total carbohydrate content [36]. The mineral content in different types of rasgulla varied in the range as follows: sodium $(\mathrm{Na})-49.64 \pm 2.62 \mathrm{mg} / 100 \mathrm{~g}$, potassium $(\mathrm{K})-25.21 \pm 0.20 \mathrm{mg} / 100 \mathrm{~g}$, manganese $(\mathrm{Mn})-$ $0.13 \pm 0.010 \mathrm{mg} / 100 \mathrm{~g}$, iron $(\mathrm{Fe})-6.22 \pm 0.17 \mathrm{mg} / 100 \mathrm{~g}$, zinc (Zn) $-1.25 \pm 0.03 \mathrm{mg} / 100 \mathrm{~g}$, and calcium (Ca) $-67.14 \pm 6.42$ $\mathrm{mg} / 100 \mathrm{~g}$ [54].

\section{Shelf life and microbial quality of rasgulla}

After execution of the cooking process, rasgullas are dipped in soaking syrup and are kept either under normal temperature storage or under refrigerated storage as per the desired shelf-life. Similar to other dairy products several factors are responsible for the shelf-life stability of rasgullas.

There are four types of enzymes responsible for degradation of dairy products [62]. Generation of lactic acid due to fermentation of lactose caused souring of dairy products, rancidity is developed in milk products due to the hydrolysation of lipids by lipase enzyme, proteinase has caused degradation of milk protein that results in bitter flavour and milk fats are churned by phospholipases. Lipase catalyzes the breakdown process of triglycerides which produces free fatty acid (FFA) which is responsible for the rancid flavour, due to release of butyric acid and short chain free fatty acid (SCFFA), and generally results in the generation of bad odours. Triglycerides account for $95 \%$ of total fat content in dairy and dairy products.

Carrot fortified rasgulla showed an increase in storage time, organic acids like galacturonic acid rupture the cellular integrity of fortifying agent (carrot) through the enzymatic action of high heat resistant pectin methylesterase and polygalacturonase with progress in storage period [25]. This enhances the acid level of syrup which causes a significant decrease in $\mathrm{pH}$ level of rasgulla and makes it unsuitable for consumption. Antioxidant property of stevia may be responsible for the decreased in $\mathrm{pH}$ value over the storage period [29].

During storage, growth of different kind of microorganisms also causes damages to the dairy products. During the production process, inferior hygiene practices may favour psychotropic bacteria growth, which ultimately encourages the process of lipolysis [63]. Generally, gramnegative bacteria, moulds, yeasts, hetero-fermentative lactobacilli, spore-forming bacteria and psychotropic bacteria are responsible for the spoilage in different dairy products. Yeasts, coliforms, hetero-fermentative lactic acid bacteria and spore-forming bacteria can all cause gassing defects in dairy products. There are evidence of milk poisoning by Campylobacter sp. [62]. The growth optimum for Campylobacter jejuni is $30{ }^{\circ} \mathrm{C}$, and their growth has been ceased at refrigeration temp. Similar to Staphylococcus aureus, C. jejuni is heat sensitive and thus constitutes a threat for raw milk only. Clostridium perfinges may sustain at high-temperature treatment and the spores may germinate in refrigeration condition. Coliform count, yeast and mould count, standard plate count (SPC), Salmonella and Staphylococcus aureus in different rasgulla samples are reported [54]. The presence of Escherichia coli in rasgulla was observed in the range of $\left(0.25 \times 10^{2} \pm 1.41\right.$ to $\left.2.50 \times 10^{2} \pm 14.14\right) \mathrm{MPN} / \mathrm{g}$ and yeast and mould count in the range of $\left(0.10 \times 10^{2} \pm 1.41\right.$ to $\left.3.8 \times 10^{3} \pm 106.07\right)$ $\mathrm{cfu} / \mathrm{g}$. Kamat et al. studied the microbiological quality of dairy-based sweetmeat products in Secundrabad and Hyderabad. As per their observation, all the rasgulla samples were contaminated with yeast and moulds [64].

With the increase in storage period total volatile compound (TVC) of traditional rasgulla as well as stevia rasgulla samples were increased [37, 38, 41]. The increment in TVC was more rapid at room temperature than at refrigerated temperature.

\section{Cultural, social and anthropological aspect of rasgulla}

Since the ancient time in Indian society dairy-based sweet dishes particularly rasgulla is considered as an auspicious sign of Midas touch (মयिण्ण মूখ) and considered as a mandatory ritual during the inauguration of a new journey and connected pervasively with spiritual, social, socio-religious and cultural rituals of the Indian subcontinent. The Chappan (56) Bhoga (જશ|ઇઇ|૧) of Jagannath temple (Puri, Odisha) is the legendary offering to Lord Jagannath, Balram and Goddess Subadhra; the Rasgulla is the one that is included in the Chappan Bhoga. It is offered to Goddess Lakshmi at the Jagannath temple. There is documented evidence of the tradition since the twelfth century [18]. As per the folk tale, the 9-day long Chariot festival (Ratha Yatra) of Lord Jagannath without consent of Goddess Lakshmi makes her angry and she prevents Lord Jagannath and his convoy from entering the sanctum sanctorum. To appease her anger, Lord Jagannath offers her rasgullas. Traditionally, it is

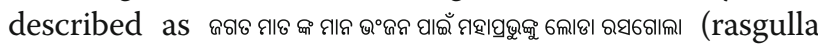
offered by Mahaprabhu for violating the values of Jagat Mata). This ritual, known as Bachinaka, is part of Niladri Bije observance, which marks the return of the gods to the temple after the Rath Yatra. In West Bengal the Durga Puja (prime festival of Bengalis) rasgulla is one of the components of the offerings, Vijaya Dasami (tenth day in the month of Ashvin, the seventh month of the Hindu Luni-Solar Calendar) is celebrated with rasgulla since the Babu culture begins (late eighteenth and nineteenth centuries). In almost all the wedding ceremony of 
Bengalis, irrespective of Hindu or Muslim religion, the groom is welcomed with rasgulla from the mother-inlaw. Rasgulla is considered as a holy symbol in a spiritual context and that is why it is used as a mandatory part of Bhaiphota (second lunar day of the bright fortnight in the Vikram Samvat (3rd A.D.) Hindu calendar month of Kartika), Last Meal of a bachelor at their parental house (আইবুড়ট |ভাত), first rice-eating ceremony of babies (অন্নপর্রাশন), sacred thread receiving ceremony (উপনয়ন) and son-in-law festival celebrated on the sixth day of bright fortnight in the Hindu calendar month of Jyeshtha (জামাইষয়ীी) (Fig. 7).

\section{Health benefits of rasgulla}

Rasgulla provides 186 calories per $100 \mathrm{~g}$ of serving since this is not only consumed during the festival time or other occasion but also in daily lives. Carbohydrate, fat and protein account for 153, 17 and 16 calories respectively of total 186 calories, which is also $9 \%$ of required calorie on daily basis. Folic acid and thiamine content of rasgulla provide energy and good for brain functioning; diabetic patients can also consume this owing to the low glycemic index. Dietary fibres present in chhana makes it to accelerate the metabolism process $[53,65,66]$. The principal ingredient of rasgulla is milk, which comprises of calcium (Ca) and vitamin D; thus consumption of rasgulla aids in strong teeth and bone formation. Milk also contains $80 \%$ casein protein as well as $20 \%$ whey protein; the essential amino acids content of these protein makes rasgulla a protein-rich product. Magnesium $(\mathrm{Mg})$ and potassium (K) present in chhana help in lowering blood sugar and blood pressure level respectively. Consumption of
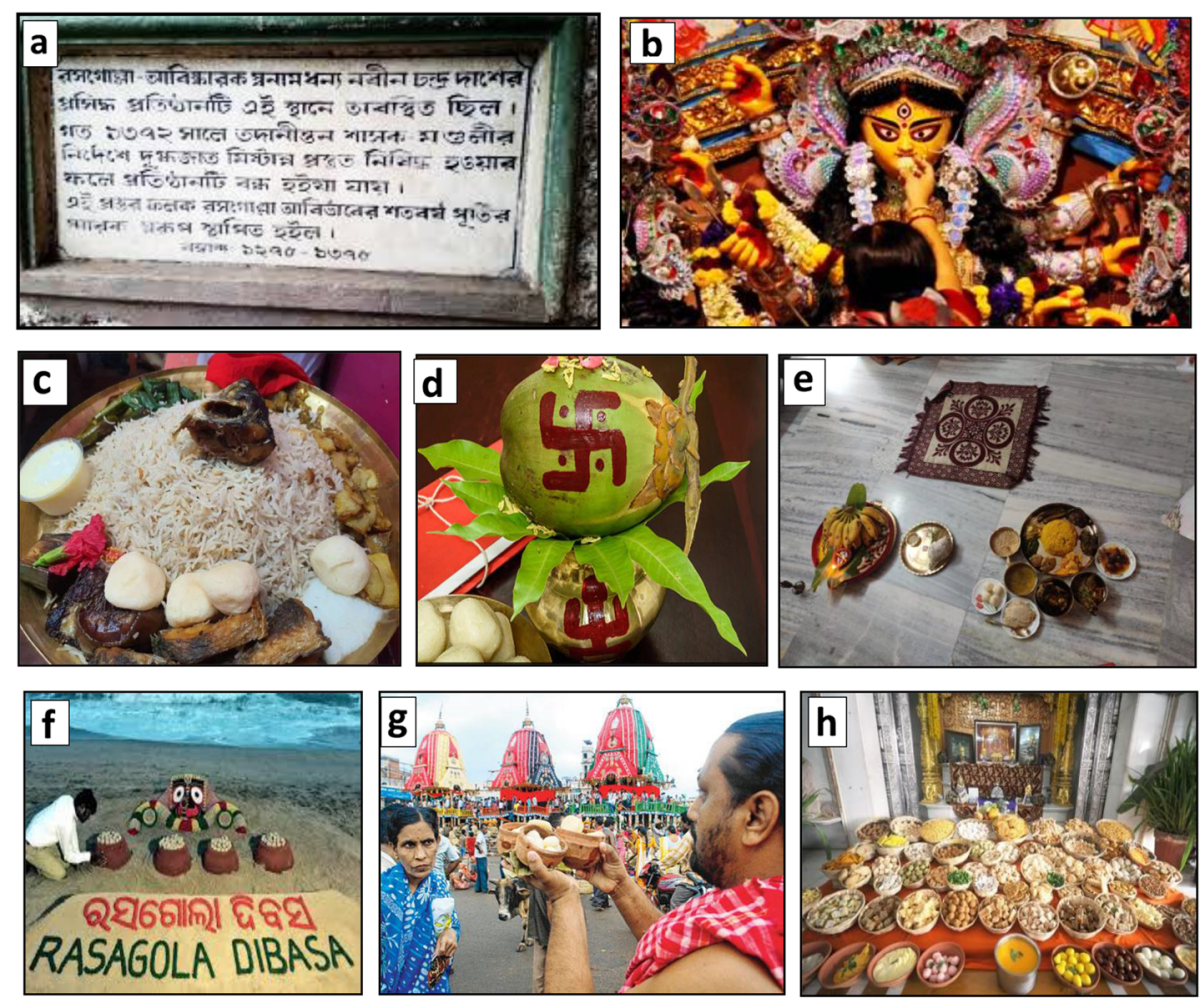

Fig. 7 Historical, social, cultural, socio-religious and geographical characteristics of rasgulla in traditional perspective. a Embalmed stone slab foundation; established in 1968 during the centenary celebration of rasgulla invention in West Bengal. b Devi Baran; rituals performed by married Hindu women before the immersion of the idol of Goddess Durga on Bijoya Dashami. c Bhog of Tarapith; offering to the Goddess Kali of Tarapith temple (established in the year of 1225) consist of rasgulla as a dessert item. $\mathbf{d}$ Mangal Ghat; rasgulla is an inevitable item during the celebration of Bengali new year (the first day of the first month of Hindu calendar Boishakh). $\mathbf{f}$ Rasagola dibasa; the return of Lord Jagannath is marked with Rasagola Dibasa, a day celebrated to let people know the history and origin of rasgullas in Odisha (By Odisha sand artist Sudarsan Pattnaik, https://incredibleorissa.com/rasagola-dibasa-odisha/). g Ratha Yatra; the chariot festival is a Hindu festival held at Odisha's Puri and it is about the return of Lord Jagannath; it is celebrated with rasgulla as one of the offering to Lord Jagannath (http://www.bhubaneswarbuzz.com/ updates/odisha-news/list-sources-point-origin-rasagola-odisha-many-know). $\mathbf{h}$ Chhappan bhog; it is the offering comprises of 56 items (rasgulla is one of the item) which are offered to Lord Jagannath every day in Shri Jagannath Temple, Puri. e Aiburobhat; in traditional Bengali wedding it is hosted by families prior to one day of wedding, it is the meals as bidding-farewell treats from their families and rasgulla is the obvious one in the platter 
immediately prepared rasgulla in hot condition helps in fight with various stomach-related disease like dysentery $[65,67-69]$.

\section{Conclusion}

As a dairy-derived sweet, rasgulla has several nutritional and health benefits. Also, rasgulla is a low-cost product which enhances its acceptability to every layer of society. Rasgulla can be a good alternative for those who have lactose intolerance as rasgulla is made from milk coagulated channa where lactase enzyme breaks the lactose sugar. To further investigate the functional health benefits of rasgulla many more works of in vivo, in vitro and in silico study are needed in the upcoming days. Nowadays, many authors are working to develop new characteristics in terms of nutritional, sensory attributes and shelf life extension of the native white-coloured rasgulla to make it more attractive. Initially being a local ethnic regional product to globally acclaimed dairy-based sweet rasgulla is continuing its journey with its own uniqueness and own identity.

\section{Acknowledgements}

We gratefully acknowledge Dr Sumit Sur, BAMS, AYUSH Medical officer, Govt of West Bengal, for his support to collect historical information for this article. We are grateful to Mr. Animesh Malakar, Assistant Manager, State Bank of India, for preparing the map of India. We also want to acknowledge Department of Food Processing Industries and Horticulture, Govt. of West Bengal, Mayukh Bhavan (4th floor), Bidhannagar, Salt lake, Kolkata, 700 091, and Orissa Small Industries Corporation Ltd, Mancheshwar Industrial Estate, Nayapalli, Bhubaneswar, Odisha 751001, for their useful information over rasgulla and Odisha Rasagola respectively.

\section{Authors' contributions}

All authors contributed to the idea and overall construction of this manuscript. The authors reviewed and approved the final manuscript.

\section{Funding}

This research work has not received any funding.

\section{Availability of data and materials}

All data and materials are used in accordance with the guideline of the Journal of Ethnic Foods as listed in the reference section. Images are personally contributed by the authors.

\section{Declaration}

\section{Competing interests}

We, the authors, declare that we have no conflict of interest in the research, authorship, and publication of this article.

\section{Author details}

'Department of Food Technology and Biochemical Engineering, Faculty of Engineering and Technology, Jadavpur University, Jadavpur, Kolkata 700032, India. ${ }^{2}$ Malda Polytechnic, West Bengal State Council of Technical Education, Govt. of West Bengal, Malda 732 102, India. ${ }^{3}$ Mirmadan Mohanlal Government Polytechnic, West Bengal State Council of Technical Education, Govt. of West Bengal, Nadia 741 156, India.
Received: 9 July 2020 Accepted: 13 July 2021

Published online: 23 July 2021

\section{References}

1. Ishak N, Zahari MSM, Talib SA. The influence of biculturalism/integration attributes on ethnic food identity formation. J Ethn Food. 2019;6(1):21. https://doi.org/10.1186/s42779-019-0024-4.

2. Karaosmanoğlu D. How to study ethnic food: senses, power, and intercultural studies. J Ethn Food. 2020;7(1):11. https://doi.org/10.1186/s42 779-020-00049-1.

3. Achaya KT. Indian food: a historical companion. Oxford University Press; 1997. p. 1-322.

4. Bhojanakutūhala. Wisdom Library. https://www.wisdomlib.org/definition/ bhojanakutuhala. Accessed 06 June 2020.

5. Debroy B. The Valmiki Ramayana. Penguin Random House India. 2017;1:1512.

6. Krishnamacharya NVR. The Mahabharata. Tirupati: Tirumala Tirupati Devasthanams; 1983. p. 1-496.

7. Kauțalya RLN. The Arthashastra: Penguin Books India; 1992.

8. Roy BC. Shri Shri Caitanya-caritamrta. Kolkata: Mahanam Sampradaya; 1992. p. 1-136

9. Das H. Sri Sri Gouriyo Baisnab Abhidhan (in Bengali): Sanksrit Book Depot: 2005.

10. Haldar J. Bengal Sweets Second Edition: Chuckervertty, Chatterjee and Co. Ltd; 1926. p. 1-155.

11. Mallik KN. Nadia Kahini (in Bengali): Rānăghăța; 1910

12. Sen S. Bangala Sahityer Itihas, Vol.I, (in Bengali): Ananda Publishers; 1991. p. 428-35.

13. Bryant EH. Krishna: a sourcebook. USA: Oxford University Press; 2007. p. 1303.

14. Kabiraj SK. Chaitanya Charitamrita: Deb Sahitya Kutir; 2015.

15. Bhowmik H. Rasogolla: Banglar Jagatmatano Abishkar: Gangchil; 2015. p. 1133.

16. Roy P. Banglar Khabar: Sahityalok; 1987

17. Bhitarachha Sebara Niyama, Record of rights, Part-III, The Odisha Gazette. 1955. http://govtpress.odisha.gov.in/notfisearch.htm. Accessed 15 May 2020

18. Bahinipati P. Jagamohana Ramayana, The Epic of Balarama Dasa: Anchor Academic Publishing; 2017. p. 1-71.

19. Senapati FM. Six acres and a third: the classic nineteenth-century novel about colonial India: University of California Press; 2005. p. 1-222.

20. Geographical Indication Registry, Banglar Rasogulla, Geographical Indication No. 533. http://ipindiaservices.gov.in/GIRPublic/Application/Details/533 Accessed 15 May 2020.

21. Geographical Indication Registry, Odisha Rasagola, Geographical Indication No. 612, http://ipindiaservices.gov.in/GIRPublic/Application/Details/612 Accessed 01 May 2020

22. Karunanithy C, Varadharaju N, Kailappan R. Studies on development of kneader and ball former for chhana in rasogolla production Part III: Quality parameters of rasogolla. J Food Eng. 2007;80(3):966-71. https://doi.org/10.1 016/j.jfoodeng.2006.06.032.

23. Karunanithy C, Varadharaju N, Kailappan R. Studies on development of kneader and ball former for chhana in rasogolla production Part l: Performance evaluation of chhana kneader. J Food Eng. 2007;81 (2):298-305. https://doi.org/10.1016/j.foodeng.2006.06.036.

24. Karunanithy C, Varadharaju N, Tiwari BD. Studies on development of kneader and ball former for chhana in rasogolla production. Part II: Development of chhana ball former and its evaluation. J Food Eng. 2007; 80(3):961-5. https://doi.org/10.1016/j.jfoodeng.2006.06.037.

25. Bandyopadhyay M, Chakraborty R, Raychaudhuri U. Physical and sensory characteristics of low fat dairy dessert (Rasogolla) fortified with natural source of $\beta$ - carotene. J Sci Ind Res India. 2007:66:757-63.

26. Suryawanshi DB, Padghan P, Patil Y, Patil RA. Development of Rasogolla prepared by incorporating Isabgol (Plantago Ovata) powder. J Pharm Innov. 2020;9:05-12.

27. Kaur G, Goswami T. Effect of defatted soy flour and concentration of stevia on physico-chemical and sensory characteristics of rasgulla. Asian J Dairy Food Res. 2018:37(3):187-91.

28. Chavan R, Prajapati P, Chavan R. Low-fat sweet syrup cheese ball (Rosogolla) manufacturing and effect of lowering fat on quality. Sens Instr Food Qty Saf. 2011;5(1):33-42. https://doi.org/10.1007/s11694-011-9109-5. 
29. Pramanick P, Roy A, Roy S, Mitra A. Value addition to Rasgulla (a traditional Indian Sweet) through Tulsi (Ocimum sanctum) leaf extract. Parana J Sci Edu. 2017:5:9-15

30. Kaur G, Goswami T. Physical and sensory characteristics of low sugar dairy dessert (rasgulla) developed at different level coconut sap syrup. J Food Sci Tech. 2020:58:343-8. https://doi.org/10.1007/s13197-020-04547-7.

31. Sarkar T, Salauddin M, Hazra SK, Chakraborty R. The impact of raw and differently dried pineapple (Ananas comosus) fortification on the vitamins, organic acid and carotene profile of dairy rasgulla (sweetened cheese ball). Heliyon. 2020;6:10.

32. Chakraborty C, Bandyopadhyay K. Textural analysis of spongy Indian milk dessert (Rasogolla) fortified with potato powder. Int J Curr Microbiol App Sci. 2017:6:2414-20.

33. Bhargava VN, Pandey VS, Shukla SG. Production of rasogolla from buffalo sweet cream buttermilk fortified with cow milk. In: 2nd World Buffalo Congress, Central Institute for Research on Buffaloes, Hisar, Haryana, vol. 292; 1988.

34. Rao OV, Singh S. Effect of Packaging M aterials on the Keeping Quality of Khoa. J Food Sci Technol. 1977:14:152

35. Kundu SS, De S. Chhana production from buffalo milk. Indian J Dairy Sci. 1972;25:159-63.

36. Haque MJ, Alam H, Islam MN, Azad MAK. Comparison of rasogolla made from fresh cow milk, fresh buffalo milk and mixture of cow and buffalo milk. Pak J Nutr. 2003;2:296-9.

37. Bandyopadhyay M, Chakraborty R, Raychaudhuri U. Effect of carrot on quality improvement of sweet syrupy cheese ball (Rasgulla). Int J Dairy Technol. 2008;61(3):290-9. https://doi.org/10.1111/j.1471-0307.2008.00412.x.

38. Chavan RS, Prajapati PS, Chavan SR, Jana A. Technology for the manufacture of diabetic rosogolla. Crit Rev Food Sci Nutr. 2014;54(7):863-8. https://doi. org/10.1080/10408398.2011.614362.

39. Mohanta B, Das H, Shrivastava SL. Rasogolla - an Indian Traditional Dairy Product. Res Rev: J Food Dairy Tech. 2016:1-10.

40. Bhattacharya DC, Des R. Studies on production of rasogolla. Part - I. Traditional method. Ind. J Dairy Sci. 1980;33:237-43.

41. Singh GP, Ray TK. Effect of milk coagulants on quality of chhana and chhana whey. J Food Sci Technol. 1977;14:205.

42. Tambat RV, Khorgade AB, Changade SP, Kaloti S. Effect of fat and maida levels on rasogolla preparation. Indian Dairyman. 1992;44:203-5.

43. Goel BK, Agrawal AK. Optimization of processing parameters for continuous rasogolla manufacturing. Indian Dairyman. 1994:46:697-9.

44. De S, Ray SC. Studies on indigenous method of chhana making. Ind J Dairy Sci. 1954;7:113-6.

45. Khan SU, Pal MA, Wani SA, Salahuddin M. Effect of different coagulants at varying strengths on the quality of paneer made from reconstituted milk. J Food Sci Technol. 2014;51(3):565-70. https://doi.org/10.1007/s13197-011-052 5-7.

46. Kumar J, Gupta VK, Kumar S, Kumar S. Effect of coagulants on the quality of chhana and rasogolla obtained from admixture of buffalo milk and butter milk. J Food Sci Technol. 2015;52(3):1736-41. https://doi.org/10.1007/s13197013-1146-0.

47. Sarkar T, Salauddin M, Hazra SK, Chakraborty R. Effect of hot air oven, microwave, microwave convective, freeze dried pineapple pulp on storage stability of casein ball (rasgulla). J Microbiol Biotechnol Food Sci. 2021; 10(04):674-9. https://doi.org/10.15414/jmbfs.2021.10.4.674-679.

48. Bhargava VN, Dubey R, Katara RV. Influence of fat level on production of chhana and rasogolla from goat milk. Small Ruminant Res. 1992;8(1-2):5565. https://doi.org/10.1016/0921-4488(92)90007-Q.

49. Iyer M. Physico chemical studies on chhana from cow's and buffalo's milk. In: M.Sc. Dissertation, Kurukshetra University, Kurukshetra; 1978. http://library. ndri.res.in/cgi-bin/koha/opac-search.pl?q=an:\%2289779\%22. Accessed 15 May 2020.

50. Reddy GMM, Arora P, Chandra P, Singh SS. Production and quality evaluation of Rasogolla prepared from milk with different levels of fat. Traditional method. Int. J Sci Engg Res. 2016;7(8):2084-7.

51. Bandyopadhyay M, Chakraborty R, Raychaudhuri U. The effect of coagulants on the texture of chhana (an acid and heat coagulated product made from milk). Int J Food Sci Technol. 2005;40(8):799-810. https://doi.org/10.1111/j.13 65-2621.2005.00979x.

52. Gupta SK, Patel AA, Patil GR, Desai HK, Ghosh BC. Texture studies on selected Indian dairy products: composition-texture relationships. Int Dairy Fed. 1993;03:176-82.
53. Singh GP, Ray TK. Effect of Milk Coagulants on the Quality of Rasogolla and Sandesh. J Food Sci Technol. 1977:14:149.

54. Sen DC, De S. Studies on calcium lactate as chhana coagulant. J Food Sci Technol. 1984;21:243-4

55. Khamrui K, Kumar S, Bandyopadhyay P. Instrumental texture profile of chhana podo as influenced by level of ingredients. Milchwissenschaft. 2003; 58:289-92.

56. De S, Ray SC. Studies on the indigenous method of chhana making. Ind J Dairy Sci. 1954;7:113-25.

57. Prodhan UK, Alam M, Sultana A, Rashid M, Das T, Akter N, et al. Quality assessment of sweetmeat (rosogolla) of Dhaka and Tangail region of Bangladesh. IOSR- J Env Sci Toxicol Food Technol. 2017;11:06-11.

58. Tewari BD, Sachdeva S. Effect of processing variables on quality of spread prepared from chhana. Ind J Dairy Sci. 1991;44:375-9.

59. Gupta SK, Gupta AA, Patel GR, Desai HK, Ghosh BC. Texture studies on selected Indian dairy products: composition, texture relationships. Int Dairy Fedn. 1993;2:176-82.

60. Desi HK, Gupta SK, Patel AA, Patil GR. Texture of Rasogolla, Effect of composition and variety in market samples. Ind J Dairy Sci. 1993:46:123-7.

61. Ravichandra MN, Mishra HN, Das H. Optimization of process parameters for the production of rosogolla from cow milk. J Food Sci Technol. 1997;34:46-

62. Katra RV, Bharagava V. Production of rosogolla from cow milk containing different levels of soy milk. Asian J Dairy Res. 1990:9:175-80.

63. Muir D. The shelf-life of dairy products: 1. Factors influencing raw milk and fresh products. Int J Dairy Technol. 2007:49:24-32.

64. Kamat MY, Sulebele GA. Microbiological quality of pedha. J Food Sci Technol. 1974;111:50-5.

65. Singh SP, Thakur SN, Chandra R. Studies on preparation of rasogolla from blend of cow milk and soya milk. Pharma Innov J. 2015;2:6-9.

66. Antonelli ML, Curini R, Scricciolo D, Vinci G. Determination of free fatty acids and lipase activity in milk: quality and storage markers. Talanta. 2002;58(3): 561-8. https://doi.org/10.1016/S0039-9140(02)00324-7.

67. Sarkar T, Bhattacharjee R, Salauddin M, Giri A, Chakraborty R. Application of fuzzy logic analysis on pineapple rasgulla. Procedia Comput Sci. 2020;167: 779-87. https://doi.org/10.1016/j.procs.2020.03.410.

68. Sarkar, T, Salauddin, M, Pati, S, Sheikh, HI, Chakraborty, R. Application of raw and differently dried Pineapple (Ananas comosus) pulp on Rasgulla (sweetened Casein Ball) to enhance its phenolic profile, shelf life, and invitro digestibility characteristics. J Food Process Preserv. 2021;45:e15233. https://doi.org/10.1111/jfpp.15233

69. Sarkar T, Nayak P, Salauddin M, Hazra SK, Chakraborty R. Preparation and characterization of sweetened pineapple cheese ball (rasgulla). 2019:92-7.

\section{Publisher's Note}

Springer Nature remains neutral with regard to jurisdictional claims in published maps and institutional affiliations.

Ready to submit your research? Choose BMC and benefit from

- fast, convenient online submission

- thorough peer review by experienced researchers in your field

- rapid publication on acceptance

- support for research data, including large and complex data types

- gold Open Access which fosters wider collaboration and increased citations

- maximum visibility for your research: over $100 \mathrm{M}$ website views per year

At BMC, research is always in progress.

Learn more biomedcentral.com/submissions 